TILTAI, 2016, 2, 115-123, ISSN 1392-3137 (Print), ISSN 2351-6569 (Online)

\title{
SELF-REGULATION IN THE TRAINING OF STUDENTS WITH DEVELOPMENTAL DELAYS
}

\author{
Lesia Prokhorenko \\ Institute of Special Pedagogy of the National Academy of Pedagogical Sciences \\ (Ukraine)
}

\begin{abstract}
The article presents the concept of self-regulation which is based on social cognitive theory of self and identity. The study involves the self-integration and specialization of psychological knowledge of subject-activity theory, structural and functional specificity of self-learning of students with developmental delays, improvement of self-interpretation of mental activity of a student in the learning process. In given conditions teaching self-regulation to students with developmental delays is considered as an act of "trial and error" analysis of conditions, the task of understanding the existing knowledge assumptions (hypotheses), thinking and planning meaningful actions and focused management of substantive actions within integrated system of effective actions and operations, including cognitive processes.

KEY WORDS: self-regulation, motivation, self-control, educational activities, students with developmental delays.
\end{abstract}

\begin{abstract}
Anotacija
Straipsnyje supažindinama su savireguliacijos samprata, kuri grindžiama socialine-kognityvine asmens tapatumo teorija. Gilinamasi ị saviintegraciją ir psichologinių subjekto aktyvumo teorijos žinių specializaciją, struktūrinius ir funkcinius studentų, turinčių raidos sutrikimų mokymosi ypatumų, savivokos apie savo mokymąsi tobulèjimą. Esamomis sąlygomis studentų, turinčių raidos sutrikimų, savireguliacijos ugdymas suprantamas kaip bandymų ir klaidų principu pagrịsta analizė, esamų žinių ir prielaidų suvokimo procesas, prasmingos veiklos planavimas ir kryptingas veiklos valdymas integruotoje sistemoje, kuri apima kognityvinius procesus.

PAGRINDINIAI ŽODŽIAI: savireguliacija, motyvacija, savikontrolè, švietėjiška veikla, studentai, turintys raidos sutrikimų.
\end{abstract}

DOI: http://dx.doi.org/10.15181/tbb.v74i2.1370

\section{Introduction}

At the present stage of psychological science, modeling and study of self-education of students with developmental delays allows you to identify the nature and intensity of the difficulties encountered in learning and develop technology of self-learning activities at all stages of the process of learning knowledge, built on a theoretical type, which helps optimize the correctional process training activities aimed at forming generalized training actions and knowledge in students with developmental delays, correcting deficiencies of regulatory processes of students with developmental delays in the learning process. 
In the context of our study, "self-regulation of educational activity" is regarded as an internal activity in which the motives and goals characterize it as a process, preferably a subjective measurement, analysis, synthesis and synthesis conditions of that solved - preferably in describing the self-regulation procedural aspects like activity.

Thus, this approach becomes especially important in the practical implementation of modeling, development of cognitive strategies and reflection on the basis of self-regulation. Therefore, the purpose of the paper is to present practical aspects of the conceptual principles of "self-learning activities" of students with developmental delays.

\section{Methods}

Theoretical methods: a deductive method (axiomatic-deductive and hypothetical) has been used for systematic description of the phenomenon under study; modelling (structural and functional) has been used for construction of the model of a social and psychological phenomenon - the self-regulation training activities students with developmental delays.

\section{Results and discussion}

In the studies of mental retardation, the problem of self-regulation was indirectly considered in the context of speech activities (Honcharuk, 2012; Milevska, 2012; Marchuk, 2008 and others); in terms of emotional, volitional and motivational areas (Bekh, 1995; Bozhovych, 1968; Vygotsky, 1956; Kotyrlo, 1974; Desi, 1991; McClelland's, 2010; Ryan, 1991 and others); the structure of self-regulation in the aspect of motivational-personal and operational technical components of educational activities schemes is outlined in the works by Vygotsky (1960), Davydov (1996), Markova (1983), Halperin (1985) and others; in terms of studying motivation, goal-setting, educational aspirations of mentally-retarded children (Konopkin, 1980; Lubovsky, 1978; Maksimenko, 2004, 2010; Menchynska, 1970; Henderson, 2010); against the background of self-control and self-esteem in educational and extracurricular activities of mentally-retarded pupils (Zharenkova, 1984; Kalmykova, 1977; Lynda, 1979; Markova, 1983; Prokhorenko, 2008; 2013; 2015); as a means of fault correction in the intellectual development of mentally retarded children (Lubovsky, 1978; Peresleni, 1972 and others). The results of the investigation show that the processes of goal-setting, programming and control aren't formed at the appropriate level, function with certain characteristics and are the result of systematic underdevelopment of all psychic functions, motivation, 
self-control and self-regulation, which has a negative effect students' learning activities.

At the present level of scientific knowledge self-regulation is regarded as a cyclical process, at the basis of which we can see structural and functional mechanisms directed at activity self-regulation. Self-regulation is formed on the basis of a child's real activities and serves as one of the most important mechanisms of activity regulation. That is why specific features of learning of mentally-retarded children determine the appropriateness of creating a new self-regulation model as an external mechanism of monitoring this activity and for the development of corresponding trends of its diagnosing and psycho-correction (Vygotsky, 1960, p. 147; Vlasova, 1975, p. 15).

The success and productivity of children's educational activities depends on the level of self-regulation components formation. These components include the motives which direct a person's activity on all the stages of its deployment, the search for the best way of achieving the goal, creating the algorithm of activities on the basis of specific conditions analysis, the choice of methods of actions and their succession, practical realization, determining the relationship between what was planned, anticipated and achieved with the goal set, activities self-correction. Thus, self-regulation does not only promote self-improvement in any activity, but it also promotes an individual's self-development.

In this regard, the issue of self-regulation of activities of pupils with special needs, especially mentally-retarded pupils, the development of psychological basis of self-regulation formation, its scientific argumentation and practical implementation in the educational process is becoming extremely topical in the sphere of scientific interests in the field of special psychology (Zharenkova, 1984, p. 17). That is why it is quite obvious that the topicality of the problem under research makes it one of the most urgent in the modern science.

The received theoretical and experimental results made it possible to determine the types of self-regulation violations in mentally-retarded pupils' learning activities. They are: immaturity of motivation for learning; low interest in activities; being unable to formulate, plan and keep to the goal of the activity (Vlasova, 1975; Lubovsky, 1978; Kopp, 1978; McClelland's, 2010; Ryan, 1991 and others); insufficient commitment, not being able to understand the importance of the orienting stage, distortion of the generalization process (Konopkin, 1980; Ehorova, 1975); increased suggestibility, inadequate self-esteem, inability to relate the received result to the activity requirements (Lynda, 1979; Markova, 1974; 1983; Maksymenko, 2004; Luria, 1979); impulsivity, underdevelopment of speech regulation, being unable to bring the work to its logical conclusion, partial perception of the example in the form of verbal instructions, being unable to stick to it while 
doing the work (Talyzina, 1998; insufficient realization of the manner of doing the work, difficulty in choosing rational methods, fragmented compliance with the assignment requirements, underdevelopment of speech mediation, being unable to spot and correct mistakes, provide proper results assessment (Vlasova, 1975; Zharenkova, 1984; Lubovsky, 1978; Prokhorenko, 2008); partially differentiated self-esteem, which mainly reflects pupil's assessment by adults, unformed level of claims (Griniova, 1998; Lebedinskaya, 1982); inadequate self-esteem, aggressive reaction orientation, negative attitude and the increased demands to the environment in frustrating situations, lack of confidence in oneself, dependence, the tendency to destructive solutions in difficult situations (Markova, 1974; Luria, 1979).

The generalization of theoretical data of the research on a child's motivation, self-control, self-esteem, self-correction and reflection in the educational process made it possible to develop the methodology of diagnosing mentally-retarded children's learning activity self-regulation (Prokhorenko, 2015, p. 145). Since a self-regulation process is a complex system which can't be observed directly, the operatialization of the research procedure included the use of three blocks of complementary techniques which ensured the assessment of motivational, operational and regulatory self-regulation components.

Self-regulation diagnosing was carried out according to the following criteria:

- interest in learning, a pupil's focus on acquiring new knowledge; focus on mastering the methods of knowledge acquisition (learning motives, related to the content of the learning activity and the process of its implementation);

- reflection (the depth of anticipation; making a decision, making a choice (generalization and differentiation of an individual's abilities and activity requirements); determining the variants of solving tasks in the new environment, which enables to realize the outcome plans and intentions);

- self-control (internal and reflecting analysis of operational action components; the analysis of actions performed for solving the task);

- self-assessment (determination of the degree of correspondence of the generally-accepted method of solving the task that enables to transfer to practical performance of specific actions (in case when there is no correspondence - a new way of achieving the goal should be created); the assessment of interim and final results.

The results received after applying all experimental techniques allowed us to see the real picture of self-regulation components formation among students with developmental delays as it's depicted in Fig. 1.

In the course of the experiment it was found out that playing motives and motives to avoid failures are dominant among students with developmental delays. 
The motives related to the educational process and studying motives such as goalsetting, comparing educational requirements to a pupil's subjective demands are at the low level. What we can see as a result is that either the transfer from motivation to action doesn't happen independently or a considerable number of wrong actions is observed and leads to many faults.

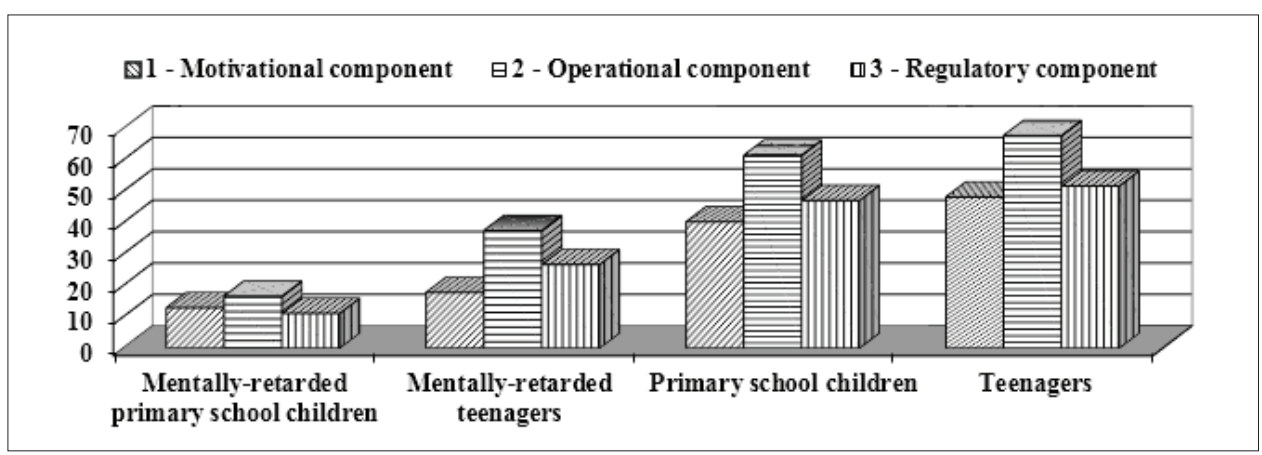

Fig. 1. Self-regulation components formation among children with normal mental development and mentally-retarded children.

The external motivation remains dominant in education, students' interest in learning when transferring from a primary school to secondary school doesn't change (such tendency is observed among $18 \%$ of mentally-retarded teens). This can be explained, on the one hand, by the changes of learning conditions, more complicated requirements, changes of the "status" and so on (Prokhorenko, 2015, p. 61). On the other hand, the reasons for prevailing external motivation are: no formation of motivational readiness to learn, low level of interest to knowledge acquisition, inadequate ideas about school requirements and learning content.

At the same time, mentally-retarded pupils possess a number of self-regulation operational component features. They are: difficulties in orientation in a learning situation which is changing, lack of planning processes and processes of results evaluation; low awareness of educational purposes and, as a result, low self-control over the educational process (78.7 \% of primary school children and 53.6\% of students in grades 5-6).

The qualitative analysis enabled us to determine certain peculiarities of selfcontrol and self-evaluation realization among students with developmental delays. These peculiarities reflect the specific character of regulatory actions implementation in the process of experimental tasks realization. They include: fragmentary task comprehension, partial or zero requirements assimilation and conservation; inability to act following the example, difficulties in determining the relations between elements of the example; difficulties in complying with the requirements in 
the process of solving problems; difficulties in choosing the method of doing the task (performing separate actions, being unable to keep to the sequence of task fulfillment); full or partial absence of interim and final results check; unconscious realization of evaluation activities ( $78.6 \%$ of primary school children and $53.6 \%$ of young teenagers). These peculiarities cause, on one hand, insufficient grounding of the implementation process and the received results, and, on the other hand, have a negative influence on a personal work evaluation (Prokhorenko, 2013, p. 119).

Let's characterize the features of self-regulatory component of students with developmental delays self-regulation. When the task conditions are made more complicated pupils' impulsive actions are observed, pupils can't notice analogy in the tasks themselves. Still after being shown the analogy pupils realize the correct method of doing the task. Being able to switch from one task to the similar one, having a few conditions changes, takes place after a child's attention if fixed on differences in task conditions (Prokhorenko, 2013, p. 99). Checking one's own work occurs very rarely, most often pupils find mistakes after being shown to them. Then they try to correct the mistakes themselves $(73.2 \%$ of primary school children and $59.2 \%$ of secondary school pupils). When being faced with difficulties the above-mentioned peculiarities become more distinct. Even being provided different kinds of assistance, the level of doing the task on one's own and finding the alternative way of dealing with the task among such children remains very low.

Similar performance is typical of most students with developmental delays. At first we can observe the interest to the work performed, at the same time, the difficulties that occur when conditions are complicated, violate the activity purposefulness, lead to temporary instruction loss, reduced activity. When dealing with the tasks with more difficult conditions or a new type of tasks, the algorithm of doing which isn't known to pupils, children make mistakes due to inadequate presentation of task conditions, pupils often use familiar proven methods, without modifying them and that leads to difficulties in switching from one method to another, in creating a new method. When students with developmental delays were asked to make an oral report about the work performed, most of them didn't produce clear analysis of the succession of doing the task. Their explanations of actions were accompanied by describing minor, secondary moments.

Thus, the analysis of psychological and pedagogical literature reveals that the mentally-retarded pupils' learning activity self-regulation process isn't formed. The development of all its components against the intellectual and speech underdevelopment takes place with delay and deviations.

The main manifestations of self-regulation motivational sphere underdevelopment are: underdevelopment of learning motivation; reliance on similar motives while doing the task (the motives are aimed at doing particular operations and ac- 
tions, they are not caused by the aim of the whole task); being unable to set distant goals for achieving one's aim; lack of understanding the relationship between academic subjects and the ability to use them in the future; the multitude of interests that leads to their superficiality and dispersion; interest instability, that leads to changes in motives hierarchy.

Self-control of primary-school and secondary school mentally-retarded children learning activities isn't formed. This is detected through being unable to analyze and plan the way of doing the task, impulsivity in the planning process, partial instruction perception, being unable to understand discrepancy between one's own work and the proposed model, being unable to find the rational way of doing the task, being unable to transfer the means of intellectual actions mentally, being unable to use the acquired knowledge in certain situations, bring the work to its logical conclusions, to control interim and final results.

\section{Conclusion}

In conclusion, the results of theoretical and experimental research of learning activities self-regulation among mentally-retarded pupils is presented in this paper. Common manifestations of unformed self-evaluation among mentally-retarded primary-school children and young teenagers are: low, partially differentiated selfesteem that mainly reflects schoolchildren assessment by adults, unformed level of claims, being unconfident in oneself, one's abilities overestimation, low criticality, stereotyped answers.

Thus, students with developmental delays self-regulation activity in the process of learning aren't formed. That is why the development of methods of selfregulation formation is considered perspective and includes the following stages of work:

1. Preparatory stage for unassisted work. Formation of pupils' repetitive actions according to the given example (the correction is made according to the activity results analysis: correct / incorrect; the development of cognitive strategies on the basis of a pupil's cognitive experience).

2. Reproductive activity (at the level of mastered course of action) - reproduction of information about different properties of the object under study; the formation of ways and methods of cognitive activity and their transfer to more complicated but homogeneous tasks; the analysis of task conditions, realization of existing knowledge, making assumptions (hypotheses), subjective actions reflection and planning and transformation of these actions on the basis of reproductive activity. 
3. Productive activity (independent use of the acquired knowledge in dealing with the tasks that go beyond the mastered mode of action: the use of inductive and deductive methods for problem solving and making conclusions).

4. Unassisted activity connected with transferring knowledge used while dealing with the task to new situations: purposeful self-regulation mechanisms development, improvement of the existing cognitive strategies, creating strategies for a higher level of a child's mental development.

\author{
Received 20160505 \\ Approved for publishing 20161015
}

\title{
References
}

Bekh, I. D. (1995). The will to identity. Kyiv: Vita, p. 202.

Bozhovich, L. I. (1968). Personality and its formation in childhood. Moscow, 454 p.

Davydov, V. V. (1996). Theory of developmental education. Moscow, $128 \mathrm{p}$.

Deci, E. L., Ryan, R. M. (1990). A motivational approach to self: integration in personality. Nebraska symposium on motivation, Vol. 38. University of Nebraska Press, Lincoln and London.

Egorova, T. V. (1975). The Development of visual-figurative thinking in children abnormal. Defectology, Vol. 4, p. $3-15$.

Galperin, P. Y. (1985). Methods of teaching and mental development of the child. Moscow, 45 p.

Griniova, M. I. (1998). In Theoretical-methodological bases of formation of the self-regulation of educational activity of student. Dissertation of candidate of pedagogical Sciences. Kyiv, $180 \mathrm{p}$.

Halperin, P. Y. (1985). Methods of teaching and mental development of the child. Moscow, $45 \mathrm{p}$.

Honcharuk, N. M. (2012). Formation of communicative skills of mentally retarded students in school groups. Kyiv, p. 23.

Jie He, Degnan, K. A., McDermott, J. M., Henderson, H. A. (2010). Anger and Approach Motivation in Infancy: Relations to Early Childhood Inhibitory Control and Behavior Problems. International Society on Infant Studies (ISIS), p. 246-269.

Kalmykova, Z. I. (1977). Features of abstraction and generalization of substantial material children with mental retardation in learning activities. Defectology, Vol. 4, p. 19-26.

Konopkin, O. A. (1980). Psychological mechanisms of regulation of activity. Moscow: Science, $256 \mathrm{p}$.

Kopp, C. B. (1987). The growth of self-Regulation caregivers and children. In N. Cisentag (ed.). Contemporaty Topics in Developmental Psychology. N. Y.

Kotyrlo, V. K. (1974). The development of volitional behavior in pre-schoolers. Kyiv, 284 p.

Lebedinskaya, K. S. (1982). The Main issues of the clinic and systematics of mental retardation. Current problems of mental retardation. Moscow, $128 \mathrm{p}$.

Lubovsky, V. I. (1978). The development of the verbal regulation of action in children (in health and disease). Moscow: Pedagogy, $224 \mathrm{p}$.

Luria, A. R. (1979). The Role of speech in the course of mental processes. The regulatory function of speech and its development. Moscow, p. 115-134.

Lynda, S. A. (1979). Didactic bases of formation of self-control in the process of independent study of students. Moscow: Higher school, $148 \mathrm{p}$.

Maksimenko, S. D. (2010). Psychological mechanisms of origin, establishment and implementation of the individual. Kyiv: European University, 152 p.

Maksimenko, S. D. (2004). The child is ready for school. Kyiv, 112 p.

Marchuk, T. F. (2008). Teaching reading to younger students in the school of intensive pedagogical correction. Guidelines for teachers. Kiev: Pedagogical thought, p. 31. 
Markova, A. K. (1974). Comparative characteristics of control and mutual control in the learning activities: experimental studies on improvement of educational process in primary school and prepare children for school. Tbilisi, $117 \mathrm{p}$.

Markova, E. V. (1983). The Formation of learning motivation in school age. Moscow, 96 p.

McClelland's, D. (2010). Research into Achievement Motivation. Team Building Training and Development.

Menchynska N. A. (1970). Issues mental development of the child. Moscow, 320 p.

Milevska, O. P. (2012). To build an understanding of texts in younger schoolchildren with delayed psychic development, Kyiv, 237 p.

Peresleni, L. N. (1972). Some features of the thinking of children with deviations in development. Defectology, Vol. 4, p. 23-30.

Prokhorenko, L. I. (2008). Features of formation of self-younger students with mental retardation (based on the tasks of mathematics), Kyiv, $263 \mathrm{p}$.

Prokhorenko, L. I. (2015). Formation of self-regulation in mathematics lessons in primary school children with mental retardation. Chernivtsi, Bukrek, $190 \mathrm{p}$.

Prokhorenko, L. I. (2015). Motivational factors of educational activity of pupils with mental retardation. Defectology. Special Child: training and education, B1, p. 58-63.

Prokhorenko, L. I. (2013). The problem of self-control at younger teenagers with mental retardation in learning activities. Scientific-methodical magazine of the Kazakh National Pedagogical University. Abay, Almaty, p. $98-102$.

Prokhorenko, L. I. (2013). The problem of self-control doctrine at younger schoolboys with a delay of mental development. Materials of IV international scientific conference: Special education: tradition and innovation, Minsk, p. 118-121.

Talyzina, N. F. (1988). The formation of cognitive activity of younger students. Moscow: Education, p. 213.

Vlasova, T. A., Lebedinskaya, K. S. (1975). Actual problems of clinical study of mental retardation in children. Defectology, Vol. 6, p. 8-17.

Vygotsky, L. S. (1956). Selected psychological researches. Moscow: APN RSFSR, 518 p.

Vygotsky, L. S. (1956). Selected psychological researches. Moscow, 518 p.

Vygotsky, L. S. (1960). The development of higher mental functions. Moscow: Publishing House of the RSFSR, $247 \mathrm{p}$.

Zharenkova G. I. (1984). Specificity of training activities. In: Children with mental rahvitiya. Moscow: Pedagogy, p. 17-20. 
